\title{
Reflets
}

Revue ontaroise d'intervention sociale et communautaire

\section{Les sentinelles du non-sens}

\section{Carole Labrèche}

Volume 1, numéro 2, automne 1995

La santé communautaire en Ontario français : défis et espoirs

URI : https://id.erudit.org/iderudit/026086ar

DOI : https://doi.org/10.7202/026086ar

Aller au sommaire du numéro

Éditeur(s)

Reflets : Revue ontaroise d'intervention sociale et communautaire

ISSN

1203-4576 (imprimé)

1712-8498 (numérique)

Découvrir la revue

Citer ce document

Labrèche, C. (1995). Les sentinelles du non-sens. Reflets, 1(2), 211-211.

https://doi.org/10.7202/026086ar

Tous droits réservés (C) Reflets : Revue ontaroise d'intervention sociale et communautaire, 1995

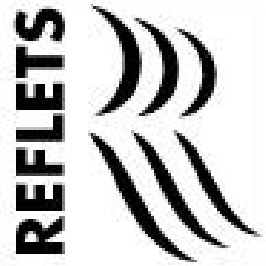

Ce document est protégé par la loi sur le droit d'auteur. L'utilisation des services d'Érudit (y compris la reproduction) est assujettie à sa politique d'utilisation que vous pouvez consulter en ligne.

https://apropos.erudit.org/fr/usagers/politique-dutilisation/ 


\section{Les sentinelles du non-sens}

\section{C arole L abrèche}

Les infirmières en sentinelle... sur le plancher psychiatrique

Elles sont de garde jour et nuit Elles vont d'une crise de larmes à un appel de détresse Elles écoutent les conversations décousues et décodent nos S.O.S.

Et si elles sont authentiques, elles représentent alors ce qu'il y a de meilleur dans la nature humaine

Elles ont compris qu'il appartient à chacun de nous d'aider celui ou celle qui chavire

$\mathrm{N}$ ous sommes tous les thérapeutes de quelqu'un quelque part

M ais elles représentent également ce qu'il y a de plus sombre et de plus inquiétant en médecine

II n'existe aucun autre endroit où le pouvoir médical est aussi absolu qu'en psychiatrie

Sentinelles du non-sens

Parmi vous il y en a qui sont de véritables phares qui éclairent les naufragés des rives intérieures 